\title{
El tema fundamental de las obligaciones de medios y de resultados frente a la responsabilidad civil
}

Felipe Osterling Parodi

Mario Castillo Freyre

\section{René Demogue, los medios y los resultados}

A pesar de nuestra opinión adversa a distinguir las obligaciones en aquellas que eventualmente serían de medios y aquellas otras que eventualmente serían de resultados, este criterio clasificatorio ha calado profundamente en la doctrina de nuestra tradición jurídica, y en la actualidad, para analizar diversas responsabilidades específicas, existen no pocos juristas que continúan asumiendo su plena validez, la misma que no es novedosa, pero que tampoco constituye una de antigua data, pues su planteamiento recién se produjo en el año 1925, cuando el famoso profesor de la Facultad de Derecho de la Universidad de París, René Demogue, publicó el quinto y último tomo de su Tratado de las Obligaciones en General.

Sin duda, las doctrinas del profesor citado revolucionaron en gran parte los conceptos sobre inejecución de obligaciones a pesar de que Demogue sólo se ocupó del tema que aquí tratamos entre las páginas 538 y 545 del quinto tomo de su Tratado.

\section{¿Y en qué consistía la doctrina de Demogue?}

El referido tratadista ${ }^{1}$ anotaba que la obligación del deudor no era siempre de la misma naturaleza, ya que podía ser una obligación de resultados o una obligación de medios.

1 René Demogue, Traité des Obligations en Général, Tomo V, pp. 538-545. Librairie Arthur Rousseau et Cie., 14, Rue Soufflot, 14, París, 1923. 
Demogue se encargó de precisar que esta división no estaba ausente de analogía con aquella otra del Derecho Penal que clasificaba a los delitos en formales y materiales. Estos últimos se caracterizan por el resultado, en tanto que los primeros se caracterizan por el empleo de medios que ordinariamente conducen a producir un resultado.

Explicando la distinción en sede de obligaciones Demogue plantea y desarrolla brevemente veintiocho ejemplos que lo llevan a efectuar la citada distinción en las obligaciones.

Jorge Horacio Alterini ${ }^{2}$ señala -de manera muy acertada- que se polemiza entre los autores sobre si debe o no atribuírsele a Demogue la paternidad de la dicotomía entre obligaciones de resultado y de medios. Sin embargo, el profesor argentino pone de relieve que aun cuando pudiera admitirse la existencia de algunos vestigios anteriores a Demogue, las teorías jurídicas deben ser atribuidas no a quienes tímidamente se atreven a hilvanar algunas consideraciones solitarias sino a aquellos que con base conceptual definida, nutren al mundo del Derecho con exposiciones sistemáticas y orgánicas

Así, a pesar de que hay quienes buscan los antecedentes de las obligaciones de medios y de resultados en el Derecho Romano, en el antiguo Derecho Francés, en algún pasaje de Domat, en Lasson o incluso en Planiol, no debe existir duda de que quien dio organicidad (aunque a nuestro criterio bastante relativa) a la distinción de las obligaciones de medios y de resultados, fue René Demogue.

\subsection{Los seguidores de Demogue}

Dentro de los partidarios de la distinción de las obligaciones de medios y de resultados, tenemos a un gran número de autores, entre ellos a Josserand, los Mazeaud, Enneccerus, Betti, Hernández Gil, Spota y Cazeaux y Trigo Represas.

Josserand ${ }^{3}$ sostiene que hay obligaciones que tienden a la obtención de un resultado determinado que deberá observar en condiciones y dirección determinadas. Expresa que las primeras son las obligacio-

2 Jorge Horacio Alterini, Obligaciones de Resultado y de Medios. En: Enciclopedia Jurídica Omeba, Tomo XX, Editorial Bibliográfica Argentina, p. 700 y ss.

3 Louis Josserand, Derecho Civil, Tomo II, Volumen II, pp. 83-84. Bosch y Cía. Editores, Buenos Aires, 1952. 
nes de resultado, en tanto que las segundas son las obligaciones de medios; en aquellas el deudor ha prometido ejecutar un acto determinado, positivo o negativo, por ejemplo, transportar los viajeros o las mercancías de un punto a otro, o construir una casa; en las segundas se ha comprometido solamente a portarse de determinado modo, en tal dirección, a poner en marcha su industria, su actividad, su talento, a prestar sus cuidados, a brindar sus esfuerzos -a fin de obtener un resultado, sin duda- pero sin garantizar el éxito.

Josserand vuelve a citar el recurrido caso del médico que promete, no curar la enfermedad, sino prestar cuidados concienzudos y atentos, conforme a los conocimientos de la ciencia.

Para Josserand esta distinción corresponde a una realidad cuyo interés se manifiesta, en primer lugar, en el terreno de la responsabilidad contractual, y más especialmente en el de la prueba; ya que la inejecución de una obligación de resultado está establecida por el hecho mismo de que el resultado proyectado no se ha obtenido, mientras que la inejecución de una obligación de medios se deduce solamente de la no observancia por el deudor de los deberes de diligencia, vigilancia, prudencia! competencia, etc., que había asumido; en una palabra, de una falta que ha cometido y cuya prueba, que incumbe al acreedor descontento, no dejará de tener dificultad. De acuerdo con esto -dice Josserand-, el paciente de un médico no obtendrá una indemnización sino en el caso de que pruebe que aquél no le ha dado los cuidados concienzudos, atentos y de conformidad a las prescripciones de la ciencia, que le debía contractualmente.

\subsection{La doctrina ecléctica}

Recuerda Jorge Horacio Alterini ${ }^{4}$ que de la misma manera como la teoría de Demogue contó con entusiastas seguidores, hubo también quienes levantaron grandes reparos. Pero algunos autores asumieron parcialmente sus doctrinas.

Jorge Horacio Alterini ${ }^{4}$ emplea los términos de Alsina Atienza, cuando expresa que el mérito de Demogue radica en haber puesto de

4 Jorge Horacio Alterini, "Efectos de la resolución del contrato por incumplimiento". En: Temas de Derecho Civil, pp. 703-704. Editorial Universidad, Buenos Aires, 1980. 
relieve la trascendencia de la pulcra delimitación del contenido de las obligaciones, en conexión con las reglas de la carga de la prueba, pero admite que sus virtudes no deben ser exageradas. En tanto, Luis María Boffi Boggero -maestro de Jorge Horacio Alterini- afirma que esta ingeniosa teoría puede facilitar la solución más justa de los siempre complejos problemas de la responsabilidad, si se le asigna un papel menos ambicioso que el perseguido por sus más fervientes partidarios.

De este modo, y colocándose en una posición intermedia, el discípulo de Boffi Boggero añade que en torno al tema no cabe ni el excesivo optimismo ni la crítica despiadada, pues la construcción de Demogue tiene el valor de haber penetrado por senderos que se consideraban suficientemente explorados, de haber indicado nuevos rumbos a quienes abordaran problemas probatorios, y aun el de haber desbrozado algunas dificultades. Pero, no obstante ello, dicha teoría no llega a conformar un edificio de sólidos cimientos e inmutables estructuras.

Para Jorge Horacio Alterini, resulta claro que el avance de la teoría no puede detenerse con críticas «del nivel de las que indican, por ejemplo, que toda obligación tiene por objeto un resultado, lo que siendo indiscutible si nos formamos una imagen genérica del resultado, no lo es si le damos el alcance referencial que a esta idea le adjudica Demoguem.

El profesor argentino agrega que si bien fines y medios se combinan en las obligaciones, es también cierto que en algunos casos esos fines están previstos en forma expresa en la obligación, como es en la de resultado; y ocurre que en otros se verifica una suerte de abstracción de esos fines respecto del contenido de la obligación, que si bien normalmente es apta para alcanzarlos, se extingue por el mero obrar diligente del deudor a quien sujeta (en lo que el citado profesor califica como obligación de medios).

Esmein, por su parte, decía que toda obligación tiene por objeto un cierto resultado, ya que de no tenerlo carecería de objeto, y el objeto es elemento necesario de toda obligación.

Para Marton, las obligaciones de medios no son más que obligaciones que consideran un resultado parcial en relación con el verdadero fin más amplio, aunque éste haya quedado fuera de la obligación.

En tanto que Ripert y Boulanger enuncian casos en que la obligación del deudor comprende tanto un cierto resultado como los medios considerados apropiados para lograrlo. 
Según Aguiar, las obligaciones de medios y las de resultado, funcionan de la misma forma con relación a la prueba del incumplimiento, porque los medios son, como el resultado, el objeto de la obligación, pues la diferencia no se encuentra allí, sino en que los medios y resultados prometidos consistan en un hacer o en un omitir, y en que la negativa sea pura, respecto de la cual quien niega, nada prueba, o que envuelva una afirmación, en la cual la prueba deba ser hecha por quien niega.

Para Busso la distinción no abarca todas las posibilidades y, por otro lado, muchas veces ambas categorías se confunden.

\subsection{Los detractores de Demogue}

Uno de los más severos críticos modernos de la distinción entre obligaciones de medios y de resultados es el profesor argentino Ernesto Clemente Wayar ${ }^{5}$, quien señala que entre ellas no hay diferencias ontológicas, siendo su distinción sólo aparente, pues en aquellas que la tradición llama «de medios» es siempre posible encontrar un «resultado", lo que se comienza a comprender cuando se acepta que en toda obligación hay medios y que en toda obligación también se persigue resultados.

Como segundo fundamento del combate a este criterio clasificatorio, Wayar sostiene que el objeto del derecho del acreedor equivale a un resultado que él espera de la conducta de su deudor y que la prestación o conducta del deudor es el medio productor de aquel resultado. Dentro de tal orden de ideas, resultado y medio son dos elementos que están íntimamente ligados dentro de la estructura de toda relación obligacional, pues constituyen parte de su esencia.

Por ello expresa que afirmar que hay obligaciones de medios en las cuales no se promete ni se debe un resultado, equivaldría a sostener que en ciertos supuestos el derecho del acreedor carece de objeto.

Sostiene el profesor citado que el hecho de que en algunas obligaciones el medio o prestación adquiera singular importancia, no autoriza a prescindir del resultado.

5 Ernesto Clemente Wayar, Derecho Civil. Obligaciones, Tomo I, pp. 128-130. Ediciones Depalma, Buenos Aires, 1990. 
Dice Wayar que, a pesar de no tener la misma jerarquía, de ninguna manera podrá decirse que en un caso el interés del enfermo en curarse no merezca la misma protección jurídica que el interés del vendedor en recibir el dinero, pues en uno y otro caso el resultado esperado por el acreedor debe gozar de idéntica protección, lo que no ocurrirá si, como punto de partida, se admite que en la obligación de medios el deudor no se compromete a obtener un resultado.

$Y$, en tercer término, Wayar expresa que en la llamada obligación de medios, la prestación (es decir, la conducta debida) persigue siempre un resultado, que no es otro que satisfacer el interés del acreedor.

Wayar afirma que sería un verdadero dislate suponer que quien adeuda un medio no se preocupe por lograr el resultado, habiendo siempre un punto en donde el objeto del derecho del acreedor se confunde con el resultado a que apuntan los medios que proporciona el deudor, por lo que considera imposible escindir los medios del resultado.

Sin embargo, no compartimos la conclusión que extrae Wayar de este problema, al decir que cuando el enfermo ${ }^{6}$ no recupera su salud, a pesar de haber seguido el tratamiento indicado por el médico, bien cabe decir que, como acreedor, su interés no ha sido satisfecho y que la prestación cumplida por el médico, con prescindencia de la eficacia o utilidad de los medios empleados, tampoco ha alcanzado su objetivo, que era, precisamente, curar al enfermo, habiéndose frustrado, según Wayar, tanto el objeto del crédito como la finalidad a que apuntaba la prestación cumplida.

Estimamos que en estas últimas expresiones existe cierta contradicción, pues por un lado no es posible decir que la prestación no ha alcanzado su objetivo, asumiendo que ella se ha ejecutado, ya que sería caer en la contradicción de siempre (de las obligaciones de medios y de resultados), desconociendo que dicho resultado se cumple con la ejecución misma de la prestación, vale decir, con la conducta del médico en hacer todo cuanto esté a su alcance para curar al paciente.

Conviene poner énfasis en que si el médico ha hecho todo lo posible para sanar al paciente y ha procedido con la diligencia ordinaria requerida, no sólo habrá ejecutado medios, sino también habrá cumplido con el resultado, pues el resultado del que hablamos no es otro que el propio tratamiento para curar la enfermedad.

6 Como puede apreciar el lector, nadie ha dejado de lado este ejemplo. 
Dicho resultado jamás ha consistido en prometer sanar al paciente. Por eso, si el paciente no se cura, no podríamos decir que el médico no habría ejecutado su prestación, porque ello implicaría afirmar que no habría conseguido los resultados a que se obligó. Igualmente, tampoco podríamos decir que no habría obtenido los resultados prometidos, pues si procedió adecuadamente, habría ejecutado de manera idónea la prestación debida.

Además de Wayar, se cuenta entre los detractores de la doctrina de Demogue, entre otros autores, a Ripert y Boulanger, Breccia, Brigant, Miccio, Carresi y Ospina ${ }^{7}$.

Como ha sido expresado por nosotros, no creemos factible dividir a las obligaciones en aquellas que se podrían considerar de medios y otras que recibirían el nombre de obligaciones de resultado(s).

Pero más allá de las consideraciones hasta aquí vertidas, hemos estimado necesario analizar con cierta minuciosidad las expresiones de quien fue creador de esta clasificación, el profesor René Demogue.

A nuestro entender Demogue, a quien no nos atreveríamos a restarle mérito alguno por haber planteado tesis tan novedosa en 1925, construyó su teoría con ejemplos usualmente contradictorios y sin una doctrina medular. No obstante ello, la inmensa mayoría de autores que conocieron la obra de Demogue, fueron persuadidos por sus ideas, las mismas que siguen siendo fuente de consideración en el análisis jurídico de diversos tratadistas contemporáneos.

Para rebatir a Demogue es indispensable recordar cuál es el concepto que asume respecto a la obligación civil propiamente dicha.

En las primeras páginas de su Tratado ${ }^{8}$, Demogue expresa que la obligación moderna traduce el concepto de la obligación tal y como ésta se forma dentro de las civilizaciones avanzadas en su evolución, pudiendo ser mejorado, al expresar que «hay obligación cuando una persona está comprometida respecto a otra a dar, hacer o no hacer».

Resulta claro que el concepto de Demogue respecto a las obligaciones civiles es el predominante en nuestra tradición jurídica y en el Derecho del siglo XX. De igual modo, este concepto ha sido asumido

7 Citados por: Manuel De la Puente y Lavalle, El Contrato en general. Segunda Parte, Tomo VI, p. 45. Fondo Editorial de la Pontificia Universidad Católica del Perú, Volumen XI, de la Biblioteca Para leer el Código Civil, Lima, 1991.

8 René Demogue, Op. cit. Tomo I, p. 3. 
por el legislador peruano -aunque nunca de manera explícita- en todos los Códigos Civiles que han tenido vigencia en nuestro país, incluyendo, obviamente, el Código de 1984.

También es necesario recordar que tal es el concepto de obligación que siempre hemos adoptado?

Adicionalmente, toda obligación implica la existencia de un objeto, el mismo que constituye la prestación, es decir la actividad humana que consiste necesariamente en un dar, en un hacer, o en un no hacer.

Hemos dicho en forma reiterada que si nos atenemos a la naturaleza de la prestación, toda obligación, de manera ineludible, es de dar, de hacer o de no hacer. Esto equivale a decir que no cabe un cuarto criterio clasificatorio.

De lo expresado se infiere claramente que la obligación es concebida de manera tradicional como el compromiso a una actividad propia, la misma que si se cumple adecuadamente constituye o configura el pago y, de esta forma, extingue la obligación.

No existen, por tanto, obligaciones que para su ejecución no impliquen realizar una actividad propia por parte del deudor, que se traducirá en un efectivo dar, hacer o no hacer, aclarando que en este último caso, es decir en las obligaciones negativas, lo prevaleciente es una inacción del deudor.

Desde esta óptica, empieza a tornarse imposible distinguir cuál sería el medio y cuál sería el resultado.

$\mathrm{Si}$ adoptamos como ejemplo una obligación de dar una suma de dinero, es claro que probablemente el deudor no requiera efectuar mayores gestiones o actividades para cumplir con ella. Podríamos imaginar el supuesto usual de que el deudor cuente con el dinero debido,

9 Como expresamos en la Primera Parte de nuestro tratado (Felipe Osterling Parodi y Mario Castillo Freyre, Tratado de la Obligaciones, Primera Parte, Tomo I, p 101. Biblioteca Para leer el Código Civil, Volumen XVI, Fondo Editorial de la Pontificia Universidad Católica del Perú, Lima, 1984), consideramos que la obligación constituye una relación jurídica que liga a dos o más personas, en virtud de la cual una de ellas, llamada deudor, debe cumplir una prestación a favor de la otra, llamada acreedor, para satisfacer un interés de este último digno de protección. Dentro de esa relación jurídica corresponde al acreedor el "poder" o "derecho de crédito" para exigir la prestación. Si el deudor, vinculado en tal forma, no cumple la prestación o la cumple defectuosamente, por razones a él imputables, responde con sus bienes de dicho incumplimiento, en razón del elemento coercitivo previsto por la ley. 
en efectivo, y cuando el acreedor fuese a cobrarle, se lo entregara en sus propias manos. En este caso, asumiendo la equivocada clasificación de obligaciones de medios y de resultado, podría decirse que dicho deudor se habría obligado a un resultado, ya que para la ejecución del mismo carecerían de relevancia los medios empleados.

Sin embargo, recurriendo al mismo ejemplo, podríamos llegar a la conclusión inversa, es decir a que se trata de una obligación de medios, si consideráramos que dicho deudor, al momento de contraer la obligación, no contaba con el dinero necesario para pagarla, y que para lograr su objetivo tuvo que realizar diversos trabajos, cobrar varios créditos, efectuar transferencias de dinero en cuentas bancarias, es decir emplear diversos medios, algunos complejos, para honrar su deuda.

Este escenario nos situaría, probablemente, ante una obligación de medios, ya que en ella las actividades previas al pago resultarían singularmente importantes para el cumplimiento de la obligación.

Como puede apreciarse en un simple y frecuente caso, como es el pago de una suma de dinero, él podría conllevar desde una actividad tan sencilla como que el deudor introduzca la mano en su bolsillo, obtenga el dinero y lo entregue al acreedor, basta un conjunto de actividades tan complejas como aquellas que formaban parte de la segunda variante de nuestro ejemplo.

Así, ¿acaso resultaría posible -dentro del criterio clasificatorio negado por nosotros- preguntamos si estamos ante una obligación de medios o ante una obligación de resultados?

Ello es imposible. Lo correcto resulta aludir únicamente a las obligaciones según su naturaleza y, en el caso propuesto, a una obligación de dar.

Como toda obligación implica un deber de conducta, es claro que siempre se va a necesitar de determinados medios (que son la actividad propiamente dicha) para cumplir la obligación, pero no existe ningún espacio vacío o algún «agujero negro» entre la actividad desplegada para el pago y el pago mismo. Esa actividad constituye parte del pago, en tanto que el pago se efectúa realizando dicha actividad.

Ni siquiera podríamos decir que se trata de dos caras de una misma moneda. Es la misma cara de la misma moneda, que debe apreciarse de manera integral y no fraccionada.

Si en la obligación más simple, que ha sido ilustrada con el ejemplo de dar una suma de dinero, resulta imposible demostrar esa diferencia 
entre los pretendidos medios y los pretendidos resultados, ya podemos imaginar que esa distinción es menos factible de ser apreciada en obligaciones cuya prestación implique la realización de actividades algo más complejas.

Siempre dentro del terreno de las obligaciones de dar, podríamos plantearnos el caso en que el deudor se obligara a la entrega de un bien cierto, por ejemplo un automóvil, el mismo que deberá conservar por el lapso de una semana, para luego entregarlo a su acreedor.

Esta es una simple obligación de dar, pero para los partidarios de las obligaciones de medios y de resultados, tal vez podría ser interesante ingresar a discutir la mucha o poca importancia que tendría el deber de conservación del bien que pesa sobre el deudor, y los escasos o considerables esfuerzos que deberá realizar para conducir el automóvil a destino y entregarlo al acreedor.

No sólo sería imposible, sino inútil, que los hombres de Derecho ingresásemos en este tipo de «sutilezas de escuela». Tal distinción carecería de interés práctico, pues al Derecho de Obligaciones solamente le concierne conocer en qué consiste la prestación asumida por el deudor y que éste la cumpla, aplicándose al tema los muy razonables principios de equidad en torno a la carga de la prueba, ya sea si la obligación se ha cumplido o si ella no se ha ejecutado.

Dentro de las propias obligaciones de dar, el lector podría imaginar el caso de aquéllas que consisten en la entrega de bienes inciertos para lo cual -como se sabe- el Derecho exige que se efectúe una elección previa a la entrega por parte del deudor (o, si ello se hubiera pactado, por el acreedor o por un tercero).

Podría decirse que si el deudor escoge, tal vez llegaría a encontrarse en una situación algo compleja, si resultara difícil determinar qué bienes conforman una calidad no inferior a la media de la especie y, ulteriormente, al efectuar la elección, se determinara que el bien es de calidad inferior a la media.

A lo expresado es posible agregar numerosas dificultades que puede asumir el deudor para entregar el bien, el mismo que (prescindiendo, para efectos académicos, de las prohibiciones legales existentes) podría consistir en un elefante de tres años de edad, que deberá ser capturado vivo en Sudáfrica y entregado al propietario de un zoológico privado ubicado en la localidad campestre de Cieneguilla, en las afueras de Lima. 
Nadie duda que ese deudor tendrá que pasar por la ejecución de una serie de actividades que revestirán un alto grado de dificultad (imaginemos el solo hecho de capturar vivo al elefante), además de realizar infinidad de trámites administrativos y ejecutar un conjunto de actividades destinadas a trasladar vía marítima a dicho elefante desde el puerto más cercano en Sudáfrica hasta el puerto del Callao, y luego conducirlo, vía terrestre, desde el Callao hasta Cieneguilla.

El cumplimiento de esta obligación, sin duda, originará problemas al deudor, pero aun imaginando que ellos fuesen muchos o pocos, nada importaría hablar de «medios" o de "resultados». Lo relevante es que el animal deberá entregarse sano y salvo al acreedor en su zoológico de Cieneguilla.

Saliéndonos de las obligaciones de dar e ingresando a las obligaciones de hacer, quisiéramos mencionar tres ejemplos que consideramos ilustrativos.

En el primero, imaginemos que un pintor se obliga con el propietario de un inmueble a pintar todos los ambientes del mismo, tanto internos como externos, con una pintura de marca y color previamente convenidos y proporcionada por el dueño de la casa.

Aquí es claro, tratándose de una obligación de hacer, que el deudor deberá adoptar una conducta determinada con el propósito de pintar efectivamente todo el inmueble. Ahora bien, el lector podrá apreciar que no resulta posible distinguir entre la labor misma de pintar la casa y el resultado que consiste en acabar de pintarla. Si ello lo fuera, tendría que asumirse la posibilidad de distinguir entre la ejecución de la prestación y su cumplimiento, lo que sería absurdo, ya que dicha ejecución y ese cumplimiento son exactamente lo mismo, en la medida que el pintor culminará de ejecutar su prestación en el preciso momento en que termine de pintar la casa, habida cuenta que mientras esté pintándola, estará cumpliendo con la prestación debida.

Sería irracional intentar distinguir en esta obligación los medios y los resultados.

Además, debe tenerse en cuenta que de considerarse que esta obligación no tiene carácter intuitu personae, ella bien podría ser ejecutada por un tercero a quien el deudor delegue el cumplimiento de su obligación, o el supuesto intermedio en que el pintor se valiera de terceros para dicho cumplimiento. En estos casos, como en todos aquellos donde resulte posible el pago por un tercero, se podría llegar al absurdo de 
interpretar que el resultado puede ser obtenido por el deudor sin haber empleado ningún medio propio, sino la ejecución por un tercero. Así, tendríamos ausencia de medios propios, pero logros de resultados propios. De esta forma, si quisiéramos aplicar a estos supuestos la teoría que combatimos, lo único que obtendríamos es un conjunto de absurdos.

Ahora imaginemos dos ejemplos de obligaciones de hacer intuitu personae.

Uno de ellos consiste en el cantante que se obliga con una empresa de espectáculos a realizar un concierto, dentro de las especificaciones que han sido materia del contrato celebrado.

En este caso, si el cantante debe instalar los equipos de luces, sonido, efectos especiales, etc., además de brindar el concierto a que se ha obligado, podríamos preguntarnos, ¿dónde comienzan los medios, dónde terminan dichos medios, dónde comienzan los resultados y dónde finalizan esos resultados?

Podría interpretarse que los «medios» comienzan con la instalación de los equipos, pero a ello podría replicarse que dichos «medios» tal vez habrían comenzado antes, cuando el cantante y su empresa empezaron a hacer las gestiones necesarias para su traslado al lugar del concierto.

Por otro lado, se podría sostener que los medios concluirían al terminar de instalarse los equipos y de haber finalizado los ensayos, tanto por parte del cantante como de su grupo coreográfico. Pero este razonamiento también podría ser contradicho, si precisamos que todo el soporte técnico, a la par que los ensayos de la obra, terminarán de ser medios útiles cuando concluya el propio cumplimiento del concierto.

Si bien podría argumentarse que el inicio del concierto representaría el principio del resultado, a ello se podría oponer el argumento de que el concierto es medio y resultado en sí mismo, al igual que todas las actividades previas a su realización, que también constituyen medios y resultados en sí mismas, imposibles de distinguir tanto en el plano teórico como en el terreno práctico.

Nuestro tercer ejemplo de obligaciones de hacer, recala en una obligación de hacer que concluye en un dar, y que es de naturaleza intuitu personae.

Un pintor, artista de nota, es contratado por el fundador de una empresa para que le haga un retrato. En este caso podríamos referirnos a que los medios van a constituir el hacer propiamente dicho de la 
obligación (es decir pintar el cuadro), en tanto que el resultado consistirá en la entrega del cuadro.

Pero este razonamiento podría ser cuestionado si pensamos que el pintor, luego de culminar su obra, deberá dirigirse al domicilio del referido personaje (si se hubiera convenido que el pago se realizara en el domicilio del acreedor), a efectos de cumplir con la entrega del cuadro. En esta hipótesis se podría argumentar que los medios no terminan sino en el momento en que el cuadro es llevado a destino (el domicilio del acreedor).

Sin embargo, el mismo caso podría ser apreciado desde una óptica radicalmente distinta, si se razonara que sólo cuando el bien llegue a destino se habría cumplido con ejecutar la obligación (vale decir, con el pretendido resultado).

Lo dicho deja en claro que podríamos llegar al caos absoluto, a la par que a un interminable y ocioso juego de palabras, cuando sabemos que en estos casos la obligación del deudor (que es una de hacer que concluye en un dar), no podría ser ejecutada si no se pinta y entrega el cuadro.

Entonces, ¿¿dónde estarían los medios y dónde los resultados? ¿O no será que ambos conceptos se encuentran indisolublemente ligados?

A continuación mencionemos un ejemplo de obligaciones de no hacer,

Es el caso de un químico al servicio de un laboratorio farmacéutico. Este profesional se encontraría obligado a no revelar durante el proceso de investigación ni al concluirlo las fórmulas y elementos en general de que está compuesto el fármaco. Aquí podríamos preguntarnos, ¿̨cuáles serían los medios y cuáles los resultados en esta obligación de no hacer?

¿Acaso podría sostenerse que el medio consiste en guardar silencio durante los meses que dure la investigación y que el resultado consistiría en que la investigación culmine manteniéndose la reserva del caso?

$\mathrm{Si}$ así fuese, llegaríamos a la conclusión de que el resultado no sería otra cosa que la consecuencia natural de la ejecución de todos los medios empleados, lo que en otras palabras significaría decir que el resultado sería la suma de los medios, esto es de todo el plazo durante el cual el químico deba guardar en secreto el proceso, los compuestos y la fórmula.

¿Pero acaso no resultaría ilógico pensar que el resultado, consecuencia natural de los medios empleados, fuera algo distinto que el fiel 
cumplimiento de los propios medios? ¿Acaso puede distinguirse entre guardar el silencio debido durante el proceso de investigación, etapa por etapa, y guardar dicho silencio luego de concluido el proceso?

En este caso se aprecia que los medios constituyen el propio resultado y que el resultado no es otra cosa que la ejecución misma de los medios. Por tanto, insistir en la pertinencia de este tipo de clasificaciones es absolutamente errado.

Por lo demás, la teoría de René Demogue -independientemente de sus méritos e indiscutible originalidad- no constituye un todo orgánico en materia conceptual, en donde prime un análisis lógico y se llegue a conclusiones de rigor científico.

La doctrina de Demogue no deja de ser un conjunto inorgánico de veintiocho supuestos señalados a manera de ejemplo, bajo el único hilo conductor de distinguir si constituyen obligaciones de medios u obligaciones de resultados.

Entonces para refutar a Demogue con sus propios argumentos, no es posible enfrentar una teoría orgánica, sino esa casi treintena de ejemplos, en donde el propio Demogue -más allá de sus conclusiones fragmentadas- deja muchísimas dudas y un número no menor de contradicciones insalvables.

Analicemos cada uno de los supuestos que para Demogue dan mérito a la construcción teórica de las obligaciones de medios y de resultados.

Luego de expresar que las obligaciones de resultado se caracterizan por el propio resultado, y que las obligaciones de medios se caracterizan por el empleo de medios que ordinariamente conducen a producir ese resultado, Demogue considera como primer supuesto de obligación de resultados al caso en el cual una persona se obliga a transportar un paquete.

Asigna a este caso tal calificación, por estimar que se espera la producción de dicho resultado. Sin embargo, el citado profesor prescinde absolutamente de analizar si el referido transporte requiere -para conseguir el resultado esperado- del empleo de los medios necesarios, los cuales podrían, sin duda, revestir, dependiendo de las circunstancias, poca, alguna o mucha importancia o dificultad. Tal vez si Demogue hubiera recalado en el empleo de dichos medios, habría llegado a la conclusión de que el ejemplo materia de tratamiento era uno de obligación de medios. 
Para nosotros, sin embargo, no existe esa inquietud, en la medida que los medios están indisolublemente ligados a los resultados, de modo tal que sería inconcebible pensar en la entrega inadecuada del paquete, sin que se hubieran ejecutado a plenitud los medios que conducen a tal efecto (y que no hubiere ocurrido un evento de caso fortuito, fuerza mayor o ausencia de culpa).

Por lo demás, ésta es, dependiendo de la perspectiva que se observe, una obligación de hacer que concluye en un dar (transportar el paquete y entregarlo) o una obligación de dar propiamente dicha. La naturaleza de la obligación podrá variar de acuerdo a la importancia que otorguemos al transporte y a la entrega del propio paquete. Sin embargo, calificarla de un modo o de otro carece de relevancia, pues tanto su transporte como ulterior entrega constituyen el objeto de la prestación debida.

El segundo ejemplo citado por Demogue es también uno de obligación de resultados, y se refiere a aquella persona que se obliga a construir un edificio.

Es evidente que a entender de Demogue, lo que importa aquí es la entrega del edificio terminado de construir, pero en este caso, al igual que en el anterior, y tal vez en grado más notorio, serán importantes los medios que el deudor utilice para la construcción del edificio, sin cuyo empleo nunca podría obtenerse el resultado, el mismo que, por lo demás, no es otra cosa que haber terminado de ejecutar la prestación debida.

Por otra parte, preocupa cuando Demogue señala que en estas obligaciones los resultados son esperados, asumiendo el peligroso criterio de sentirse "dueño del futuro", ya que a priori jamás podrá saberse si se conseguirá el resultado que se busca, por más que el deudor haga todo lo que esté a su alcance para obtenerlo.

No menos polémico resulta el tercer ejemplo de Demogue, que califica como una obligación de medios, al considerar que el banco, cuando contrata con un cliente el alquiler de una caja de seguridad, sólo está obligado a adoptar ciertas medidas de precaución, custodia, conservación y vigilancia para con dicha caja.

Aquí Demogue señala que el banco únicamente se obliga a ello y no al resultado de que el cliente pueda encontrar incólumes los bienes que hubiera depositado en la caja de seguridad.

No vemos qué existe de especial en esta obligación, pues en ella, como en cualquiera otra, el deudor se obliga a ejecutar una prestación. 
En este caso el banco estaría obligado a ejecutar una prestación de hacer, que implica un comportamiento propio de custodia respecto de la caja de seguridad del cliente, al igual que asume una prestación de no hacer, en el sentido de no abrir ni manipular en modo alguno la caja de seguridad o su contenido.

Por lo demás, en estos casos resultaría de plena aplicación el régimen probatorio de inejecución de obligaciones, en la eventualidad de que, por ejemplo, se hubiese producido la pérdida total o parcial, por robo, del contenido de la caja de seguridad que el cliente ha contratado en la bóveda del banco.

Ante dicho incumplimiento, conforme a la legislación peruana, deberá presumirse que él obedeció a culpa leve del banco, pudiendo el cliente afectado agravar la responsabilidad de la institución financiera, si probara que dicho incumplimiento obedeció a dolo o culpa inexcusable. Dentro del mismo régimen legal peruano, el banco, a su turno, tendría la posibilidad de eximirse de responsabilidad, demostrando que el incumplimiento ocurrió a pesar de haber empleado la diligencia ordinaria requerida por las circunstancias de la obligación, o por causas derivadas de caso fortuito o fuerza mayor o de ausencia de culpa.

En el caso analizado de las cajas de seguridad de los bancos, vemos que poco importa hablar de medios o de resultados. Simplemente corresponde referirnos a las obligaciones asumidas por el banco, a su cumplimiento, a su eventual incumplimiento y a las causas que hubieran motivado este incumplimiento.

En cuarto lugar Demogue, cita otro ejemplo de una obligación que califica como de medios: la del guardián que se obliga a vigilar una propiedad, caso en el cual, según Demogue, esa persona sólo debe adoptar precauciones y no promete que el dueño la encontrará intacta.

Resulta claro que en este caso nos encontramos ante una obligación de hacer intuitu personae, a través de la cual dicho guardián se compromete a resguardar el bien de la manera más adecuada. Pero, ‘acaso podría sostenerse que el guardián únicamente es contratado para estos efectos y no para entregar el bien al propietario, cuando corresponda, en las mismas condiciones en que lo recibió? ¿Acaso sólo interesan las precauciones que adopte y no los resultados que obtenga fruto de dichas precauciones? ¿Cómo se podría desligar el cumplimiento de la prestación de hacer del resultado mismo, a la par que cómo se podría desligar dicho resultado del correcto cumplimiento de la obligación asumida? 
Utilizando la clasificación creada por el propio Demogue. podríamos llegar a sostener que en este caso estaríamos en presencia de una obligación de resultados y no de una de medios. Pero tan absurdo sería sostener lo primero como lo segundo, pues simple y llanamente nos encontramos frente a una obligación de hacer.

El quinto ejemplo citado por René Demogue es el del conductor de un vehículo, respecto de quien considera que sólo contrae una obligación de medios con el viajero, en relación al equipaje de mano que este último no haya hecho registrar.

Ante todo, el equipaje de mano no registrado como equipaje acompañado, constituye parte de las pertenencias del viajero, como sería el caso del bolso para una señora, del maletín de un ejecutivo, del juguete de un niño o de alguna prenda de vestir que el pasajero lleve en la mano para la eventualidad de algún cambio climático en el lugar de destino o en el propio trayecto.

$\mathrm{Si}$ el transportista permite que los pasajeros porten estos equipajes, podría no estar obligado a su custodia en términos tan absolutos como sí lo estaría respecto al equipaje registrado, pero sí estará obligado a permitir que estos pasajeros puedan portar, con la comodidad del caso, el equipaje de mano, y a permitirles que lo depositen en algún lugar del vehículo a fin de que puedan llegar a destino con total resguardo de su integridad.

En este caso resulta imposible, a todas luces, determinar cuál sería el medio y cuál sería el resultado.

Se trata, en suma, de una simple prestación que consiste en hacer todo lo posible para que el equipaje no sufra daños en el transporte, además de la prestación de no hacer que se asume para evitar que dichos bienes sean manipulados por el propio transportista o por la tripulación de manera indebida.

El sexto ejemplo citado por Demogue es el del médico, quien no promete la curación del paciente sino sólo sus cuidados. Es evidente que dentro de su lógica califica a tal obligación como una de medios.

El ejemplo del médico ha sido y es utilizado de manera reiterada por toda la doctrina de nuestra tradición jurídica, prácticamente como un arquetipo de la pretendida distinción entre medios y resultados.

En términos generales es desde luego imperativo que un médico actúe con ética y de modo diáfano, obligándose a tratar a su paciente con la mayor diligencia y con los conocimientos que posea, a fin de 
brindarle el tratamiento que considere más adecuado para la curación o alivio de su dolencia. Si la pregunta se refiere a cuál es la obligación que asume el médico, resulta claro que es una de hacer, la misma que consiste en realizar todo cuanto esté a su alcance para lograr la mejoría del paciente.

No podría sostenerse en este caso que el médico se haya obligado a curar al paciente, porque ello constituiría una promesa irresponsable.

Entonces podemos llegar a concluir que en el caso de la obligación del médico respecto al paciente, no es que el intentar curarlo sea obligarse a los medios para obtener necesariamente un resultado ulterior, ya que el resultado ulterior no ha sido materia de la obligación asumida por el médico con el paciente.

No entendemos la razón por la cual la obligación de tratar a un paciente deba ser considerada como un medio y no como un fin en sí mismo, ya que sólo si se prometiese la curación los intentos del médico por lograr que sane el paciente tal vez pudieran ser vistos como un medio. Pero, a nuestro entender, tal promesa sólo constituiría un acto ajeno a la ejecución de la prestación asumida.

El séptimo ejemplo que inquieta a Demogue es saber si el hospedante tiene respecto al turista una obligación de resultados en relación al equipaje que este último hubiera llevado al establecimiento.

El establecimiento de hospedaje está obligado a mantener la custodia que las circunstancias, categoría y demás consideraciones aconsejen respecto a dicho equipaje, custodia que constituye parte de una obligación de objeto plural, con prestaciones de hacer y de no hacer.

Nos preguntamos, jen este caso cuáles serían los medios y cuáles los resultados? Sin duda, resultados y medios se identifican con la ejecución de la propia prestación.

Luego, en octavo lugar, Demogue aborda el tema de la obligación de seguridad que tiene la empresa respecto del obrero, la misma que él califica como de medios, en contraposición a un sector de la doctrina que la considera de resultados.

Nos parece irrelevante la discusión abierta por Sainctelette y recogida por Demogue, pues es claro que toda empresa, y especialmente las dedicadas a cualquier actividad industrial, deberán tomar las medidas de seguridad adecuadas, con el propósito de que no se produzcan accidentes entre los trabajadores, en la misma medida en que los trabajadores deberán adoptar todas las precauciones necesarias a fin de evitar 
cualquier accidente. De esta forma, al tener ambas partes deberes impuestos tanto por la ley como por la relación contractual que las vincula, si ocurriese un accidente, el caso se reduciría a probar quién incumplió con esos deberes de seguridad, lo que, en buena cuenta, representa conocer quien fue el culpable del accidente producido.

En noveno lugar, Demogue piensa que la obligación del conductor de un automóvil respecto a las personas que transporta, es una obligación de resultados.

Para nosotros es claro que se trata de una obligación de hacer propiamente dicha y que no merece un tratamiento distinto -en cuanto al régimen probatorio- que cualquier otra obligación nacida de fuente contractual y que hubiera sido materia de incumplimiento. Nos parece absurda la sutileza planteada por Demogue en el sentido de que el conductor no promete tomar todas las medidas ordinarias para el transporte y observar las precauciones que imponen la prudencia y los reglamentos de tránsito, sino que solamente se obliga a conducir al pasajero sano y salvo a su destino.

Esta distinción no resulta razonable, en la medida que podría ser imposible conducir a un pasajero -sano y salvo- a destino si se contravinieran todas las medidas de seguridad (incluyendo las más elementales) y se violaran todos los reglamentos de tránsito (incluyendo aquellos preceptos de observancia básica). Lograr el resultado sin el empleo de los medios idóneos equivaldría a algo así como ganar la lotería sin haber comprado un boleto.

No está demás decir que el régimen probatorio en esta materia deberá ser el general de inejecución de obligaciones contractuales.

Igualmente inútil es la discusión que Demogue plantea como décimo supuesto, cuando se pregunta si en el contrato de remolque marítimo se promete el resultado o solamente hacer todo lo posible para conseguir tal resultado.

Aplicamos a este caso, mutatis mutandis, las mismas consideraciones formuladas con ocasión del supuesto inmediatamente anterior.

Como décimo primero, décimo segundo y décimo tercer ejemplos, Demogue considera como obligaciones de resultados la del inquilino, la del depositario y la del comodatario, respecto a la devolución del bien que se les ha entregado.

En estos tres casos podemos apreciar con mayor nitidez la irrelevancia de tal distinción. 
Decimos esto, porque cualquiera de los tres contratantes está obligado a conservar adecuadamente el bien y a mantenerlo en el estado en el que lo recibió, devolviéndolo en esas condiciones, sin mayor deterioro que el que imponga el uso normal del bien (en los casos del inquilino y del comodatario) e intacto (en el caso del depositario).

Para nosotros es claro que los tres contratantes deberán conservar adecuadamente el bien; que el inquilino y el comodatario deberán usarlo de manera responsable, sin ocasionarle daños, y que el depositario no podrá usar el bien, salvo autorización expresa del depositante. Así, teniendo como premisa que el bien debe ser devuelto en el mismo estado en el que se entregó, si hubiera sufrido deterioro cualquiera de los tres contratantes mencionados se encontraría obligado a repararlo (si ello fuera posible) y a devolverlo en las mismas condiciones en que lo recibió. Todo esto, abordando el problema a grandes rasgos, y con prescindencia de la causa que hubiera ocasionado el daño, lo que no constituye materia de este estudio.

De otro lado, en los tres casos señalados por Demogue como obligaciones de resultado, también podría sostenerse, empleando su misma lógica, que se trata de obligaciones de medios, en la medida que si los bienes alquilados, prestados o depositados, no se cuidaran adecuadamente o no se repararan (si ya hubiesen sufrido daño), el deudor estaría imposibilitado de cumplir con su obligación.

En décimo cuarto lugar, y calificándola como una obligación de medios, Demogue cita el caso del mandatario o representante que promete trabajar con la debida prudencia para ocuparse de intereses ajenos (los del mandante).

¿Aquí cuáles serían los medios y cuáles los resultados? ¿Acaso en un supuesto de inejecución no tendrían que responder sólo quienes hubiesen actuado culposa o dolosamente? ¿Acaso podría conseguirse el objeto del mandato, si no se actuara ciñéndose a los términos de la relación contractual?

En décimo quinto lugar, y en sede de responsabilidad extracontractual, estima Demogue que un chofer sólo tiene una obligación de medios (la de actuar con prudencia), estando obligado a no causar daño a nadie.

Esta distinción es verdaderamente bizantina.

Más allá de lo relativo a los reglamentos de tránsito, vale decir a cuestiones de orden administrativo, es claro que para el Derecho de 
Obligaciones interesará que el conductor no cause un daño a otro, pues será el hecho generador del daño aquél que originará la aplicación de los preceptos de responsabilidad extracontractual, en la misma medida en que si no hubiese daño no habría obligación que indemnizar.

Ahora bien, si el conductor causó daños a terceros, tendrá el deber de indemnizarlos, a menos que demuestre que el daño se originó sin su culpa o que obedeció a caso fortuito, a fuerza mayor o a culpa de la víctima, habiendo actuado dicho conductor con la diligencia ordinaria requerida por las circunstancias.

En décimo sexto lugar, Demogue califica como obligaciones de resultados a aquellas derivadas de responsabilidad por riesgo creado, comprendiendo dentro de las mismas el supuesto de responsabilidad del comitente (décimo séptimo supuesto), de los hechos de los dependientes (décimo octavo supuesto), de los hechos de los animales (décimo noveno supuesto), de los daños producidos por las cosas (vigésimo supuesto), de la ruina de los edificios (vigésimo primer supuesto) y de los daños causados por menores de edad (vigésimo segundo supuesto).

Por nuestra parte, pensamos que dentro de la propia lógica de Demogue sería cuestionable la calificación de estas obligaciones como de resultados, pues aquellos eventuales responsables, en los ejemplos a que hemos hecho referencia, tendrían que haber adoptado todas las precauciones del caso con el propósito de que no se produjeran daños a terceros respecto de aquellos bienes, animales, cosas, negocios o personas que tuvieran bajo su custodia o responsabilidad.

Posteriormente, en su vigésimo tercer supuesto, Demogue califica como obligación de resultados aquella que la ley impone al inquilino respecto al arrendador, en caso de que este último sufra las consecuencias de un incendio producido en el inmueble, considerando que ello debe ser así porque el inquilino ha prometido al arrendador un resultado, consistente en la restitución del inmueble.

No vemos en esta hipótesis ninguna obligación susceptible de calificarse como de medios o de resultados. Simplemente se puede decir que la responsabilidad derivada de la inejecución de obligaciones obedece a una infracción de la obligación de conservar el bien de manera óptima (obligación de hacer) o, en todo caso, de la obligación de no hacer consistente en abstenerse de realizar cualquier acto que pudiera implicar riesgo o peligro para la conservación del inmueble. 
Aquí también se confunden los medios y los resultados. Es imposible que ellos sean distinguidos. En todo caso, simplemente debe hablarse de obligaciones de hacer y de no hacer; $y$ de si éstas se cumplen o no.

Más ilógico resulta todavía cuando Demogue distingue la obligación que acabamos de mencionar (que califica como de resultados) de aquella que tiene el inquilino respecto del vecino, en relación a los eventuales daños que le causan un incendio producido en el inmueble que ocupa (vigésimo cuarto supuesto). Demogue considera que en este caso el arrendatario no debe a su vecino un resultado, sino únicamente el tomar las medidas impuestas por la prudencia.

Pensamos que en este caso no son necesarias mayores consideraciones para combatir el planteamiento de Demogue, pues tal distinción obedece más al criterio de que la primera obligación es una nacida de fuente contractual, en tanto que la segunda proviene de fuente extracontractual, hecho que en este caso no puede conducirnos a otorgar soluciones jurídicas distintas a un mismo problema (todo ello, naturalmente, con prescindencia de la mecánica probatoria).

Independientemente de los supuestos calificados por Demogue como obligaciones de medios y de resultados, deviene en equivocada la idea expresada por él, compartiendo el parecer de Gabba, cuando estima que en todos los contratos que versen sobre los servicios de una persona experta, no nos encontraremos en presencia de una obligación de carácter contractual, pues dicho acto otorga al deudor la facultad de emplear su libertad, de modo tal que si hace un uso indebido de ella se configuraría un supuesto de responsabilidad extracontractual.

Esta distinción es contraria a la razón y al Derecho. Para calificar a una obligación como contractual o extracontractual debe prescindirse de su contenido u objeto, ya que en estos casos lo importante es la fuente que le ha dado origen o nacimiento.

Resulta de evidencia palmaria que si la obligación ha nacido de un contrato, deberá calificarse como contractual, en tanto que si hubiera tenido origen en la ley, recibirá el calificativo de legal o extracontractual, ocurriendo lo propio respecto al calificativo que merece la inejecución de obligaciones originadas en el incumplimiento de obligaciones de uno u otro tipo.

Como vigésimo quinto supuesto, Demogue califica a la obligación que asume un abogado como una de medios (al igual que la del mé- 
dico, supuesto ya mencionado por Demogue y del cual nos hemos ocupado en páginas precedentes).

Es absurdo considerar que el abogado de conducta responsable asuma con su cliente una obligación de medios. Si de lo que estamos hablando (ya que pueden existir infinidad de variantes) es del caso en que el abogado se obliga a asumir la defensa de un cliente en un proceso judicial (típico ejemplo académico de nuestra tradición jurídica sobre este particular), dicho profesional se estará obligando -entre otras prestaciones- a un hacer, el mismo que consiste en defender a su cliente de acuerdo a sus conocimientos, aptitudes y capacidades, respetando las normas básicas que imponen el Código de Etica Profesional, la Ley Orgánica del Poder Judicial, así como las leyes procesales y sustantivas pertinentes.

Sin perjuicio de volver sobre el punto al tratar este tema! como singularmente ilustrativo, de la teoría del hecho ajeno (promesa de la obligación o del hecho de un tercero), es claro que el abogado cumple con ejecutar la obligación asumida, si es que se ciñe a aquello que ha sido materia de convenio con su cliente, con prescindencia del resultado del proceso judicial, vale decir, de si gana o pierde el juicio, o si se produce la culminación del mismo con una resolución que no ampare plenamente las pretensiones del demandante (o denunciante) ni del demandado (o denunciado).

¡Cuándo terminarán de entender algunos autores que en un supuesto de esta naturaleza tampoco puede hablarse de medios ni de resultados, ya que si se quisiera emplear esta terminología, las actividades desplegadas por el abogado (es decir los medios) constituirían a su vez el propio resultado, el mismo que no consiste en otra cosa que asumir una idónea defensa de su cliente en el proceso!

De otro lado, hace mal Demogue en expresar que las actividades de todo obrero (vigésimo sexto supuesto), sea del grado que fueren, constituyen una obligación de resultados.

Si lo que llevó al profesor francés a esta afirmación es el hecho de que la actividad del obrero implica un menor razonamiento que el del abogado o el del médico, está equivocado, pues esta situación resulta irrelevante, ya que lo que importa es que la obligación sea ejecutada. Aquí tampoco hay medios ni resultados. Simplemente hay una obligación que tiene que cumplirse. 
Pero más grave es equiparar la actividad de cualquier obrero con la de un arquitecto (vigésimo séptimo supuesto), señalando que en este caso también la obligación será de resultados, pues dichos resultados pueden ser conseguidos de manera casi certera con la tecnología apropiada.

De esta última afirmación surgiría la interrogante de si en e! fondo Demogue consideró a las obligaciones de medios como aquellas cuyo resultado es incierto (pues, dada la tecnología existente, no se podría asegurar que el mismo se vaya a producir), en tanto que calificaría como obligaciones de resultados a aquellas «de cumplimiento casi certero» (siempre atendiéndose a los avances de la ciencia y de la tecnología).

Nada nos puede hacer predecir, por más avanzados que sean los medios con los que contemos, que, dentro de la distinción de Demogue, se va a llegar a cumplir un resultado. Y, además, avanzados o no que sean los medios, siempre se les tendrá que emplear como actividad, la que, en sí misma, constituye ejecución de la prestación debida (con lo que se entremezclan y confunden -una vez más- los inútiles conceptos de medios y de resultados).

Finalmente, Demogue concluye sus ejemplos con el de la obligación de dar un bien cierto (vigésimo octavo y último supuesto), que la considera como una obligación de resultados, y a cuyo análisis aplicamos los conceptos que ya hemos explicado, salvo el caso de transferencia de un bien inmueble determinado, que luego examinamos.

Para concluir nuestros comentarios en torno al tema de las obligaciones de medios y de resultados, debemos subrayar que tal distinción nos parece inútil, en la medida que todo deudor, cualquiera que sea su actividad, profesión, u oficio, se obliga a ejecutar una obligación, ya sea de dar, de hacer o de no hacer. Y, precisamente, cumplirá dando, haciendo o no haciendo aquello a que se obligó.

Los hombres de Derecho no debemos partir del supuesto que todas las personas, cuando contraen una obligación, asumen necesariamente un deber de conducta que deba ir más allá de lo que convengan como acreedor y deudor.

Nos explicamos.

En el típico caso del médico, utilizado a manera de ejemplo por Demogue y comentado por nosotros, consistente en el profesional que recibe en consulta a un paciente, es evidente que el paciente, el médico y la sociedad en su conjunto tienen el más ferviente deseo de que el paciente se cure de la dolencia que padece. Pero no deben confundirse 
estos buenos deseos con aquello que constituye el objeto de la obligación, pues el mismo consiste en hacer todo lo que esté al alcance de sus conocimientos médicos para sanar al paciente.

Creemos que esta confusión entre los buenos deseos de que se presente una situación posterior óptima condujo a Demogue, entre otras razones, a pretender diferenciar, jurídicamente hablando, los medios de los resultados, cuando medios y resultados son exactamente lo mismo, porque en el Derecho de Obligaciones, salvo determinados casos de excepción que serán analizados de inmediato, nunca podrá conseguirse un resultado sin el empleo de los medios necesarios. Esto equivale a decir que, también en el lenguaje jurídico, nunca podrá pagarse, en estricto, si no se ejecuta la prestación.

\section{La obligación de transferir la propiedad de un bien inmueble cier- to como supuesto excepcional a la regulación común de las obli- gaciones.}

Como se sabe, el principio por el cual la sola obligación de enajenar hace al acreedor propietario de un bien inmueble cierto, salvo disposición legal diferente o pacto en contrario (recogido por el articulo $94^{\circ}$ del Código Civil Peruano de 1984), es un precepto que viene siendo reiterado desde los inicios de nuestra codificación civil, pasando por el Código de la Confederación Perú-Boliviana de 1836 y por los Códigos de 1852 y de 1936.

Pero dicho principio no nació en el Derecho Peruano, sino que tuvo su origen en el Derecho francés, con el Código Napoleón. Esto obedeció a la enorme revalorización, luego del proceso revolucionario, del derecho a la propiedad privada, el mismo que fue mencionado en la Declaración de los Derechos del Hombre y del Ciudadano como un derecho natural del hombre.

Por otra parte, cuando la estabilidad retornó a Francia, primero con el Directorio y luego con Napoleón Bonaparte, el derecho de propiedad fue consolidándose y se adoptó como el principal de los derechos naturales del hombre. Se podría decir que en los hechos se consagró su sacralización, tal como se había establecido en la Declaración referida.

Sin duda que como la libertad, la independencia y la seguridad económica exigían en Francia la existencia de un derecho de propiedad sólido 
y estable, el Código de 1804 elaboró todo el sistema de protección de las obligaciones y contratos, en absoluto resguardo del más importante derecho patrimonial sobre el que se construía esa nueva sociedad.

De ahí que el Code estableció un principio absolutamente excepcional, el mismo que no tenía otra finalidad que asegurar una electiva transferencia del derecho de propiedad.

De esta forma, los artículos $1182^{\circ}, 1582^{\circ}$ y $1583^{\circ}$ acogieron el principio por el cual cuando un deudor se obligaba respecto al acreedor a transferirle la propiedad de un bien cierto, dicha transferencia operaba acto seguido del nacimiento de la obligación de enajenar.

El sistema francés, con sus bondades y defectos, fue adoptado por la legislación civil peruana, probablemente sin mayor reflexión, pues los motivos que llevaron al legislador de 1804 a incluir esas normas, no fueron materia de discusión explícita en el Derecho peruano.

Ahora bien, dentro de nuestra línea de pensamiento, en el sentido de que los contratos -por sí mismos- no transfieren la propiedad de bienes, sino que ellos simplemente son creadores, modificatorios, regulatorios o extintivos de obligaciones, tenemos entonces que el contrato sólo es capaz de crear la obligación de transferir la propiedad de un bien inmueble cierto, pero no de transferir dicha propiedad.

Esto significa que cuando hablamos de la transferencia de propiedad, nos estamos refiriendo a la ejecución de la prestación debida.

Entonces pueden surgir, como de hecho surgieron, algunas interrogantes: ¿cómo podría entenderse que la obligación de transferir una propiedad inmueble en el Perú constituye la ejecución de una prestación, si toda prestación consiste en una actividad humana de dar, hacer o no hacer?

Y ello obedece a que el artículo $949^{\circ}$ del Código Civil prescribe que la propiedad inmueble se transfiere por la sola obligación de enajenar, sin que el deudor necesite ejecutar la prestación, la misma que se ve cumplida por la simple aplicación de la norma legal.

Lo expresado obedece a que el precepto nacional, por tener su fundamento en los textos franceses, entiende que tratándose de la más importante de las obligaciones susceptibles de ser asumidas por los seres humanos, no da oportunidad para que el deudor incumpla (sometiéndolo al régimen general de inejecución de obligaciones), sino que la propia ley -a través del artículo $949^{\circ}$, en el caso peruano- da por ejecutada automáticamente la prestación. 
Hemos querido mencionar el artículo $949^{\circ}$ del Código Civil, pues el mismo constituye una excepción al cumplimiento de las prestaciones por parte de quienes asumen tal obligación, ya que en estos casos es la propia ley la que la ejecuta.

Finalmente, y como conclusión, el lector podrá apreciar que en este caso tampoco resulta posible hablar de obligaciones de medios y de resultados. ya que la obligación de transferir la propiedad de un bien inmueble se cumple por mandato de la propia ley, inmediatamente después que se contrae tal obligación.

\section{La promesa de la obligación o del hecho de un tercero como excepción al régimen común de ejecución de las obligaciones.}

Cuando criticamos la teoría de René Demogue sobre las obligaciones de medios y de resultados, nos referimos, entre otros, al ejemplo relativo a las obligaciones de los abogados para con sus clientes, como un caso ilustrativo.

No es que dicho tema constituya el único supuesto del razonamiento que vamos a efectuar en el análisis de las obligaciones de medios y de resultados, sino que, al ser uno de los mencionados con mayor frecuencia por la doctrina, y, por tanto, de los más conocidos, nos da pie para abordar la materia.

Si la doctrina del Derecho de Contratos omite pronunciarse sobre el particular, valgan estas páginas para plantear la necesidad de una reflexión acerca del tema, a la vez que para emitir nuestro propio parecer.

Siguiendo un hilo conductor del problema, nos referiremos concretamente al caso del abogado que, al asumir el patrocinio de un proceso judicial, se obligue con su clientes a "ganar el juicio».

Aquí podría pensarse que Demogue tenía razón y que existen obligaciones de resultados (por oposición a las de medios), siendo este supuesto el de una obligación de resultados.

En una hipótesis como la descrita, no deseable dentro del campo de la ética profesional, pero común en la práctica, el abogado únicamente está prometiendo que su cliente vencerá en el proceso, vale decir, que su pretensión (si se tratara de un proceso civil, por ejemplo) será declarada fundada, en última instancia, o que el cliente ganará el juicio por 
la ocurrencia de cualquier otra circunstancia que conduzca a similares resultados.

Existe una frase muy antigua en relación a los procesos judiciales, la misma que reza que «en un juicio no basta tener la razón sino que a uno se la quieran dar". Esto significa que todo proceso judicial, por más razones jurídicas sólidas que una persona aduzca, implica necesariamente un grado de aleatoriedad, en la medida en que nadie puede tener la absoluta certeza que será vencedor. Esto porque ni las partes ni sus abogados son quienes se encargan de resolver el litigio. Las sentencias judiciales son pronunciadas por los magistrados y, por ello, son terceros en relación a las partes contratantes (abogado y cliente).

De esta forma, cuando el abogado promete a su cliente que vencerá en el juicio, no se trata de otra cosa que de la promesa del hecho de un tercero.

La promesa de la obligación o del hecho de un tercero es un tema que ha merecido interesante regulación en los artículos $1470^{\circ}, 1471^{\circ}$ y $1472^{\circ}$ del Código Civil Peruano de 1984, al igual que tuvo anterior tratamiento, entre otros, por el Código Civil francés, el Código Civil chileno. el Código Civil colombiano, el Código Civil ecuatoriano, el Código Civil venezolano de 1880, el Código suizo de las Obligaciones, el Código Civil argentino, el Código Civil italiano de 1942, el Código Civil venezolano de 1942, el Código libanés de las Obligaciones, el Código Civil de la Provincia de Québec y el Código Civil boliviano de 1976 y luego por el Código Civil paraguayo de 1987.

La promesa de la obligación o del hecho de un tercero surge para el Derecho y es recogida por el Código Civil peruano de 1984, dentro del marco de algunas figuras en las cuates se produce cierta apertura de la estricta aplicación del principio res inter alios acta, en conjunto con el contrato por persona a nombrar y el contrato en favor de tercero.

El Código Civil, independientemente de regular la promesa de la obligación o del hecho de un tercero dentro de la Parte General de Contratos (artículos $1470^{\circ}, 1471^{\circ}$ y $1472^{\circ}$ ), emplea esta figura de manera directa y específica únicamente al tratar en el contrato de compraventa, en el contrato de donación y en el contrato de arrendamiento, la promesa de la obligación o del hecho de un tercero, cuando el promitente promete al promisario que el tercero (propietario del bien) celebrará con dicho promisario el respectivo contrato de compraventa, donación o arrendamiento. 
Estudiando en su conjunto al Código Civil respecto a esta materia, se llega a la conclusión de que la promesa de la obligación o del hecho de un tercero es una figura o mecanismo contractual a través del cual el promitente puede prometer al promisario que un tercero asumirá con respecto a este último cualquier obligación posible y lícita, o que dicho tercero realizará cualquier acto de las mismas características.

Nosotros no coincidimos con ninguno de los pareceres esbozados por la doctrina de nuestra tradición jurídica sobre su naturaleza.

Si bien, por una parte, resulta seductora la posición que sostiene que estamos frente a una obligación de garantía (pues si el tercero no cumple el hecho o no se obliga de acuerdo a lo prometido por el promitente, este último deberá indemnizar al promisario), por otra parte también reviste interés un último planteamiento esbozado por el doctor Manuel de la Puente, en el sentido de que el promitente, además de lo señalado, asume el deber de actuar con la diligencia ordinaria requerida con el propósito de persuadir a ese tercero a fin de que asuma una obligación frente al promisario o cumpla un hecho en su favor.

Pero los referidos planteamientos merecen algunas objeciones de fondo.

La primera estriba en que el promitente nunca está prometiendo la realización de una prestación propia, ya sea de dar, de hacer o de no hacer, pues aquello que constituye objeto de la promesa, es decir objeto de la obligación del promitente, es que el tercero haga algo o se obligue a algo (previamente convenido entre promitente y promisario).

Es probable que en un caso de esta naturaleza, el promitente despliegue determinadas actividades a fin de lograr que el tercero realice el hecho o contraiga la obligación. En buena cuenta, podría interesar al promitente ejecutar estas gestiones, si ellas van a conducirle a obtener un resultado positivo respecto de aquello que ha prometido.

Pero debe quedar en claro que el promitente no está prometiendo que él mismo hará algo, vale decir que no está obligándose a la ejecución de una prestación propia, sino a que se ejecute una prestación ajena. Así, si hiciera algo no es porque ese hacer constituya objeto de su obligación, sino que actuaría por considerarlo conveniente a sus intereses, pues bien podría mantenerse en total inactividad, o que equivale a decir que no hiciera absolutamente nada y, no obstante ello, se produjera el hecho o la obligación del tercero. 
Indudablemente la promesa de la obligación o del hecho de un tercero es una figura que no puede ser explicada dentro de los cánones habituales del Derecho de Obligaciones y Contratos, partiendo de la idea de que en este caso se produce el quebrantamiento de la existencia de la prestación, entendida como la actividad que debe realizar el deudor para pagar, consistente en un dar, un hacer o un no hacer.

Decimos esto porque en la promesa de la obligación o del hecho de un tercero, el deudor no debe dar, hacer o no hacer absolutamente nada, ya que simplemente ha prometido que se producirá la obligación o el hecho del tercero.

Ahora bien, el lector podrá preguntarse ante una situación de esta naturaleza, si el compromiso asumido por el deudor (promisario) no consistiría exactamente en una obligación civil, ya que ésta tiene por objeto una prestación, y en este caso no la habría.

Ello es cierto, ya que si se quisiera explicar el fenómeno de la promesa de la obligación o del hecho de un tercero a través de las doctrinas tradicionales, o cediéramos a la tentación de calificar a este contrato como uno de garantía, necesariamente tendríamos que ingresar al terreno de las obligaciones de medios y de resultados, distinción que combatimos.

Entonces, ¿cuál es la naturaleza jurídica del compromiso asumido por el promitente?

El promitente asume para con el promisario el deber jurídico de contenido patrimonial consistente en que un tercero se obligue o realice un hecho determinado. Debemos poner énfasis en que se trata de un deber jurídico y no sólo de un deber moral, pues se crea un vinculo, reconocido por el Derecho, a través del cual el promitente sólo cumplirá cuando se produzca el hecho ajeno o la obligación ajena.

Pero este deber jurídico de contenido patrimonial, con características atípicas que le permitiría integrar una clasificación más de las obligaciones y deberes, carece de prestación propia, ya que aquí el promitente (deudor), en estricto, no debe realizar absolutamente nada para que la prestación del tercero se cumpla (para que el tercero se obligue o haga algo).

Pensamos que el Derecho debe reconocer que en estos casos estamos en presencia de una obligación sui generis, pues no tiene prestación propia sino prestación ajena y el tercero no se encuentra obligado a cumplir con ella. 
El segundo elemento que nos resulta de interés, y que respalda el criterio de que el deber jurídico aludido no deja, en rigor. de ser una obligación, es que la figura posee indudablemente el elemento de coerción, propio del Derecho de Obligaciones.

Nos explicamos.

Si la promesa asumida por el promitente, cuando fuere incumplida, no acarrease ninguna consecuencia jurídica, la promesa de la obligación o del hecho de un tercero no sería algo distinto a un deber moral, pues sería irrelevante que se cumpliera o no lo prometido (en cuanto a las consecuencias jurídicas respecto del deudor promitente). A éste le daría lo mismo si se cumple o incumple el objeto de la promesa, porque en caso de incumplimiento no se vería expuesto a sanción alguna.

Es claro que si alguien promete algo, sin la existencia de una contraprestación que ejecute el promisario a favor del promitente, no habríamos salido del campo de los deberes morales. Todo esto se reduciría a un conjunto de «buenas intenciones", que no merecerían que el Derecho se detenga a analizar y a dar sustento.

Ahora bien, imaginemos un caso similar, pero en el cual el promisario sí asumiese frente al promitente la obligación de pagada una contraprestación, si es que el tercero ejecutara o se obligara a lo prometido por el promitente.

En este caso, el ejemplo ya se acercaría más a uno con contenido jurídico, pues el compromiso asumido por el promitente, de tener éxito, va a merecer una compensación o retribución por parte del promisario.

Pero el tema todavía no se encontraría completo, en la medida que se hubiera pactado que si el tercero no ejecutara el hecho prometido o no se obligara, el promitente no debiese pagar absolutamente nada al promisario. Una situación así podría cuestionarse en el sentido de si podría formar parte del Derecho de Obligaciones, en la medida que el tema carecería del elemento de coerción, ocurriendo -en la prácticaque el promitente deudor podría -tranquilamente- «dejar de cumplir», perdiendo el derecho a la contraprestación convenida, pero viéndose libre de cualquier deber indemnizatorio frente al promisario.

Sin embargo, hemos empleado una expresión condicional pan referirnos a si este caso formaría parte del Derecho de Obligaciones, en tanto que al no haberse obligado el promitente a la ejecución de una prestación propia, sino a una prestación ajena, dicha prestación, en lo que respecta a las actividades propias del promitente, sería una prestación vacía. 
Así, visto el tema desde esta perspectiva, no repugnaría al Derecho que el promitente, ante el incumplimiento de su promesa, no tenga deber alguno de indemnizar al promisario.

Sin embargo, admitimos que una situación como la descrita resultaría altamente discutible.

Pero la regulación que el Código Peruano ha dado al tema nos releva de tener que plantearnos un supuesto como el que acabamos de anotar, en la medida en que a través del artículo $1470^{\circ}$ se establece que el promitente quedará obligado a indemnizar al promisario si es que no se llegara a cumplir lo prometido.

Es más, el artículo $1472^{\circ}$ establece que incluso podría pactarse de manera anticipada el monto de dicha indemnización.

Resulta, no obstante, discutible que el artículo $1471^{\circ}$ establezca que la indemnización a cargo del promitente tiene carácter de prestación sustitutoria de la obligación o del hecho del tercero. Decimos esto, porque la expresión "sustitutoria" nos hace recordar la mecánica de las obligaciones facultativas, en donde existe una prestación principal y una accesoria, debiendo el deudor cumplir con la prestación principal, pero teniendo la facultad de sustituirla con la accesoria.

Sin embargo, en la obligación facultativa la sustitución a que hemos aludido no opera de manera subsidiaria, ante la imposibilidad de cumplimiento de la prestación principal, pues si la prestación principal fuese nula o imposible de cumplir, la obligación facultativa se extinguiría, aunque la prestación accesoria fuera válida o posible de cumplir (argumento del artículo $1160^{\circ}$ del Código Civil peruano).

En la promesa de la obligación o del hecho de un tercero, el deudor no goza de esa facultad de sustitución en el pago, ya que mientras esté vigente el plazo pactado para que se produzca el cumplimiento de la obligación o el hecho del tercero, el promitente no podría liberarse pagando la «indemnización» sustitutoria.

De lo expuesto podemos concluir que la prestación sustitutoria de la promesa de la obligación o del hecho de un tercero, no es una prestación que represente una alternativa para el pago.

Nos queda claro que de no cumplirse la obligación o el hecho del tercero, el promitente deudor deberá pagar la indemnización, como una especie de sanción, no precisamente resarcitoria, como veremos más adelante. Pero también resulta claro que si se incumpliera lo prowetido y se pagara la indemnización, el promitente deudor habría 
cumplido, pero no aquello que prometió, pues el tercero ni se obligó ni realizó acto alguno.

El promitente paga la prestación indemnizatoria con carácter subsidiario, ya que el Derecho entiende que si él no tenía, dentro de la esfera de sus posibilidades, la de cumplir por sí mismo con aquello que prometió, sino se produce el hecho o la obligación del tercero dicha promesa incumplida (por más que haya implicado una prestación ajena) no podría quedar impune. De ahí que se prevé la referida prestación sustitutoria, que en realidad, como se ha dicho, tiene carácter subsidiario, la misma que sí implica una prestación en sentido estricto, pues puede y debe ser ejecutada por el promitente deudor.

La denominada prestación sustitutoria no tiene carácter indemnizatorio, aunque así la califique el Código Civil, por cuanto entendemos que no está destinada a resarcir daños y perjuicios, sino simplemente a reemplazar la promesa que no se ha podido cumplir.

Por ello, nada tendría de extraño que la denominada prestación sustitutoria de la promesa de la obligación o del hecho de un tercero, consista en bienes distintos al dinero, $\mathrm{o}$, incluso, en prestaciones de diversa naturaleza, ya sean de hacer o de no hacer. Este es, sin duda, otro rasgo importante que distingue a este tipo de obligaciones de aquellas de carácter resarcitorio, las mismas que -por regla general y salvo casos de excepción como los de una cláusula penal- siempre consistirán en dinero.

De lo expuesto también puede deducirse que cuando en virtud de lo establecido por el artículo $1472^{\circ}$ del Código peruano se pacta anticipadamente el monto de la indemnización, dicho convenio no tendría la naturaleza jurídica de una cláusula penal, pues su función, igualmente, no sería resarcitoria, sino meramente compensatoria.

Uno de los temas que resulta imprescindible abordar al referirnos a la promesa de la obligación o del hecho de un tercero, es el de la responsabilidad por el incumplimiento de dicha promesa.

De acuerdo a los principios generales que inspiran la figura bajo estudio y, en especial, el contenido de los artículos $1470^{\circ}, 1471^{\circ} \mathrm{y}$ $1472^{\circ}$ del Código Civil, queda claro que es regla general que en caso de incumplimiento de la promesa, el promitente deudor tiene que ejecutar la prestación subsidiaria (mal llamada sustitutoria). Pero lo que no se encuentra explícito es si dicha prestación subsidiaria deba pagarse sea cual fuere la causa que hubiese ocasionado el incumplimiento de la promesa. 
Estamos planteando, en buena cuenta, el tema de que una circunstancia no imputable al promitente, sobreviniente a la celebración del contrato, determinase que al tercero le fuese imposible cumplir con el hecho o no pudiera contraer la obligación que constituye el objeto de la promesa.

El doctor Manuel de la Puente y Lavalle ${ }^{10}$ sostiene que si este fuere el caso, la obligación principal (vale decir, el cumplimiento de lo prometido) quedaría extinguida por aplicación del artículo $1316^{\circ}$ del Código Civil, cuyo principio general es que la obligación se extingue si la prestación no se ejecuta por causa no imputable al deudor.

Entendemos que estos serían los sanos principios aplicables al caso, pues la promesa debería seguir, si se quiere de manera indirecta, la suerte de la prestación que constituye el objeto de dicha promesa.

Decimos esto, por cuanto la promesa de la obligación o del hecho de un tercero contiene una "prestación" que hemos denominado como "vacía», en el entendido de que en estricto no existe prestación alguna, ya que quien es deudor y promitente no se encuentra obligado a ejecutar ninguna prestación propia.

Ahora bien, teniendo en consideración lo expuesto, resultaría injusto que el promitente tuviera que responder por la imposibilidad de la promesa cuando ella obedeciera a caso fortuito, fuerza mayor o a alguna causa que no fuera imputable al deudor promitente.

Sin embargo, debemos precisar que cuando nos referimos a causa no imputable al deudor promitente, aludimos sólo al hecho de que sin su culpa deviniera en imposible la ejecución de la prestación ajena (por ejemplo, que muriese el tercero antes de vencido el plazo pactado entre promitente y promisario para que dicho tercero ejecutara el hecho o contrajese la obligación).

En relación al tema de la diligencia ordinaria, debemos expresar que resultará absolutamente indiferente, para estos efectos, si el deudor promitente actuó o no con la diligencia ordinaria requerida por las circunstancias.

Ello queda claro, en la medida que tal promitente no se ha obligado a la ejecución de un acto propio, de modo que no podría exigírsele que

10 Manuel De la Puente y Llavalle, El Contrato en general, Segunda Parte, Tomo VI, pp. 87-88. 
actúe con diligencia, cuando ni siquiera está obligado a desplegar actividad alguna, como ya ha sido expresado.

Eso significa que podríamos encontrarnos en el caso extremo de un deudor que realizara todos los actos que se encuentren a su alcance para lograr que se haga efectivo el hecho o la promesa por parte del tercero y si, a pesar de ello, el tercero no cumpliese con el hecho o no contrajera la obligación, el promitente deudor habría Incumplido la promesa y, en razón de ello, tendría que ejecutar la prestación de carácter subsidiario.

Ahora bien, más allá de lo expresado en estas páginas, nada impediría que el promitente deudor pactase con el promisario acreedor que el primero asuma las consecuencias si la prestación objeto de la promesa deviniese en imposible por causa no imputable, incluyendo, por cierto, el caso fortuito o fuerza mayor. Este convenio ampliatorio de responsabilidad sería perfectamente lícito conforme al artículo $1317^{\circ}$ del Código Civil.

Para finalizar nuestras apreciaciones sobre la promesa de la obligación o del hecho de un tercero, debemos subrayar que la importancia de haber abordado este tema se deriva del típico ejemplo del abogado litigante, en la modalidad de aquel que promete a su cliente un "resultado", vale decir, que vencerá en el proceso.

En síntesis, podemos afirmar que en este caso queda claro que los medios y os resultados se confunden, no existiendo distinción o línea divisoria alguna entre ellos, dado que dicho abogado ha prometido a su cliente un hecho que no depende del citado profesional, sino de terceros, esto es de los magistrados que resuelvan la causa.

\section{A modo de conclusión}

Para concluir con el tema fundamental de las obligaciones de medios y de resultados frente a la responsabilidad civil, como ha podido apreciar el lector, hemos querido exponer la teoría de René Demogue que dio nacimiento a esta materia y luego citar algunas posiciones esbozadas por la doctrina, pero fundamentalmente hemos deseado dejar en claro nuestra tesis adversa a distinguir las obligaciones en aquellas que pudieran ser de medios y otras que pudieran ser calificadas como de resultados. 
Para combatir a Demogue hemos recurrido a analizar puntualmente todos los supuestos en que dicho profesor basó su teoría. De ello queda claro que resulta artificiosa la distinción, ya que toda obligación implica necesariamente la existencia de un objeto denominado prestación, la misma que el deudor va a tener que ejecutar a favor del acreedor; y esa prestación -forzosamente- será de dar, de hacer o de no hacer.

Por ello hemos subrayado que la ejecución de las prestaciones no es algo que se origine "por arte de magia», sino que necesariamente implicará la realización de actividades por parte del deudor.

Esas actividades no constituyen otra cosa que la ejecución o pago de una obligación civil. De allí que si la obligación se ejecuta como aspira el Derecho, estaremos en presencia de un cumplimiento idóneo, y, en la medida que el mismo se aleje de dicha idoneidad, entraremos al terreno del cumplimiento parcial, tardío o defectuoso o, simplemente, habremos llegado al campo de la inejecución total de la obligación.

Es así que la ejecución de una prestación no puede ser vista como medio para cumplir, pues ejecutar una prestación constituye el cumplimiento propiamente dicho de la misma.

En consecuencia, no es que hayan medios y ulteriores resultados. Si se percibe al medio como algo independiente del resultado, llegaríamos al absurdo de sostener que una prestación se cumple o ejecuta (medio) pero no se paga (ausencia de resultado).

El Derecho de Obligaciones se ciñe estrictamente a aquello que ha sido convenido por las partes, de modo tal que no es otro el régimen de cumplimiento.

Sin embargo, al abordar el tema de las mal llamadas obligaciones de medios y de resultados, hemos desarrollado caso por caso el ensayo de Demogue, con el fin de demostrar lo artificioso de esa distinción.

Y también hemos expuesto, con el propósito de evitar malos entendidos, dos puntos que han concitado nuestra particular atención: la obligación de transferir la propiedad de un bien inmueble cierto y la promesa de la obligación o del hecho de un tercero.

Ocurre que la obligación de transferir la propiedad de un inmueble cierto, como lo hemos expresado, constituye en el Perú un supuesto excepcional a la regulación común de las obligaciones.

Recuérdese, al respecto, que el artículo $949^{\circ}$ del Código nacional establece que la sola obligación de enajenar un inmueble determinado 
hace al acreedor propietario de él, salvo disposición legal diferente o pacto en contrario. Esto significa que la obligación de transferir la propiedad, excepcionalmente tiene por objeto una prestación que no va a ser ejecutada por el deudor, sino que la propia ley la da por ejecutada inmediatamente después de haber nacido, prestación sui generis (que hasta podríamos denominar "vacía») que constituye una situación atípica con base en razones históricas propias del nacimiento y contexto del Código Civil Francés, las mismas que se instalaron en el Derecho Peruano desde el Código de la Confederación Perú-Boliviana de 1836.

El segundo supuesto de excepción al régimen común de ejecución de las obligaciones que hemos abordado es el relativo a la promesa de la obligación o del hecho de un tercero, materia de la que el Código nacional se ocupa prolijamente -como en su oportunidad lo señalamos- en sus artículos $1470^{\circ}, 1471^{\circ}$ y $1472^{\circ}$.

Dentro del análisis que hemos efectuado sobre la materia, existe un punto que podría llevar al lector a considerar equivocadamente que en este caso podríamos estar ante un supuesto de obligaciones de resultados (por contraposición a las llamadas obligaciones de medios).

$\mathrm{Y}$ es que en la promesa de la obligación o del hecho de un tercero el promitente cumple frente al promisario cuando se produce el hecho ajeno o cuando el tercero se obliga. Pero, tanto en uno como en otro caso, el promitente deudor ha prometido algo que él mismo no va a ejecutar $\mathrm{y}$, además, puede decirse con fundamento que ha prometido algo cuya ejecución se encuentra total y absolutamente fuera de su alcance, lo que más allá de razones fácticas se explica objetivamente en no haberse obligado a la ejecución de una prestación propiamente dicha.

Pero en el caso de la promesa de la obligación o del hecho de un tercero tampoco hay medios ni resultados, en estricto. Únicamente hay cumplimiento con la realización del hecho por parte de una tercera persona o de la naturaleza, o cuando ese tercero contraiga una obligación con el promisario.

Se trata de un apasionante tema que si bien es propio del Derecho de los Contratos, resulta indispensable abordarlo en Derecho de Obligaciones, para salvar cualquier objeción en torno a las supuestas obligaciones de medios y de resultados.

Por lo demás, estos dos casos de excepción (la obligación de transferir propiedad y la promesa) tienen autonomía conceptual propia y 
características históricas sui generis, que de manera alguna pueden conducirnos a apreciarlos fuera de su contexto o, peor aún, a extraer de ellos conclusiones indebidas.

Como corolario de todo lo expuesto, debemos subrayar que si se aceptaran las diferencias esbozadas por un sector de la doctrina entre obligaciones de medios y de resultados, esto afectaría considerablemente el tema probatorio en caso de inejecución de obligaciones.

Sin embargo, como dicha diferenciación es artificiosa, la prueba debe efectuarse de acuerdo con lo prescrito en el Código Civil peruano de 1984 , vale decir que se regirá por lo dispuesto en los artículos $1329^{\circ}$, $1330^{\circ}$ y $1331^{\circ}$ de dicho cuerpo sustantivo ${ }^{11}$. En tal sentido, fue claro para el legislador nacional que tal distinción resulta ficticia, razón por la cual no la aceptó.

Lima, septiembre del 2000.

11 Los textos de los referidos numerales son los siguientes:

Artículo $1329^{\circ}$.- «Se presume que la inejecución de la obligación, o su cumplimiento parcial, tardío o defectuoso, obedece a culpa leve del deudor".

Artículo $1330^{\circ}$.- «La prueba del dolo o de la culpa inexcusable corresponde al perjudicado por la inejecución de la obligación, o por su cumplimiento parcial, tardío, o defectuosay.

Artículo $1331^{\circ}$.- «La prueba de los daños y perjuicios y de su cuantía también corresponde al perjudicado por la inejecución de la obligación, o por su cumplimiento parcial, tardío o defectuoso". 